\title{
Global Financial Reform Needed, But Unlikely
}

\author{
Kwame Sundaram Jomo ${ }^{1}$
}

Published online: 6 June 2017

(C) Society for International Development 2017

\begin{abstract}
The 2008-2009 global financial crisis and other recent related crises since the end of the 20th century have their origins in the anarchic international financial liberalization and the 'non-system' which emerged following the unravelling of the Bretton Woods international monetary system. The multilateral United Nations system must fill the void to credibly guide efforts to build an international monetary and financial system to support sustainable development for all.
\end{abstract}

Keywords Credit · Crisis - Investment · Liberalization · Globalization

After almost four decades, there has been a still growing backlash against globalization, welling up over the last decade. Most people associate economic globalization with trade liberalization, but the evidence suggests that financial globalization has grown far more significantly than trade globalization, especially since the 1980 s.

\section{International Financial Liberalization}

Advocates of international financial liberalization or financial globalization presumed that by reducing barriers to capital flows among countries, capital would flow from the capital rich countries to the capital poor countries. In fact, however, the converse has happened, and there has been a net transfer of resources from the Global South to the Global North. About half the flows to the North went to

\footnotetext{
Kwame Sundaram Jomo

jomoks@yahoo.com

$1 \quad$ Kuala Lumpur, Malaysia
}

the United States, although of course, there were variations over time with changing circumstances. Part of the reason for this preference for investing in the United States, e.g. by buying US Treasury bonds, was precisely because of its dominant role in the post-war international monetary and financial system, even after the original Bretton Woods arrangements were unilaterally revoked in 1971 by US President Richard Nixon.

Although there was a significant increase in financial investments in developing countries from the mid-1990s, there have not been corresponding increases in gross domestic fixed capital formation, which continues to be driven by other considerations. In other words, real investments in developing countries have not increased despite the big increase in financial investments from abroad. Hence, such financial investments have not contributed much to the growth of the real economy.

The actual record of financial globalization has been the converse of what its advocates claimed. First, capital flows have not gone from the capital-rich to the capital-poor except for brief episodes, for example, to East Asia in the early and mid-1990s. Second, the cost of funds has not declined for many reasons. Third, while some old sources of financial volatility and instability have undoubtedly been reduced, new sources have been introduced. Furthermore, liberalizing capital flows has had many effects, some of which have been negative. To minimize exchange rate appreciation, it has been necessary to incur high sterilization costs in order to mitigate some of these problems. Hence, net benefits have been significantly reduced.

It is important to recognize that short-term capital flows were especially problematic. They did not contribute in any significant fashion to investment, let alone growth. Rather, they contributed to asset price bubbles involving shares and real estate, and of course, there were associated bubbles, 
such as in the construction industry as well. During the 1997-1998 Asian crisis, there were very significant financial asset market bubbles which caused a great number of problems for these economies. Furthermore, there was also a great deal of over-investment due to the availability of cheap credit, resulting in excess capacity. Over-investment typically led to excess industrial capacity. This, in turn, led to cut-throat competition which made it very difficult for some new industries to survive. The availability of cheap credit also resulted in significant consumer binges, resulting in avoidable household and personal debt which became hugely problematic later. Such short-term capital flows have therefore worsened instability and increased the inherent procyclicality of the international financial system.

\section{International Coordination}

Why is global co-ordination so necessary? There are two main reasons. One major problem before the Second World War was the lack of international macro-financial coordination. So, in 1944, at the end of the Second World War, President Roosevelt convened the United Nations Conference on Monetary and Financial Affairs - better known as the Bretton Woods Conference - even before the United Nations (UN) was set up the following year in San Francisco. After almost a month of meetings, the conference created the basic framework for the international monetary and financial system after the war, including the International Monetary Fund (IMF) and the International Bank for Reconstruction and Development (IBRD), or World Bank.

This system reflected compromises made among the negotiating government representatives, and later served post-war reconstruction and early post-colonial development reasonably well until 1971, when it was unilaterally ended by US withdrawal during the presidency of Richard Nixon because of the mounting inflation and unsustainable budget deficits, mainly due to the costly Vietnam War. The US unilaterally withdrew from its core commitment to ensure full US dollar convertibility to gold at the agreed rate. Thus, the unilateral US action did not involve an orderly transition from the Bretton Woods system to any multilaterally agreed alternative.

Meanwhile, very little has been done to reform the international monetary and financial system as a whole. The absence of the universally accepted reserve currency system has led to a situation where global imbalances have become quite unsustainable. The leading international monetary economist of the post-war period, Robert Triffin, described the post-1971 arrangements as amounting to a 'non-system' since the end of the Bretton Woods system.

Now, with the international monetary system essentially the cumulative outcome of ad hoc responses to perceptions of various incentives, deterrents and challenges, the need for coordination is all the more urgent. Financial re-regulation is critical, particularly with the deregulation as well as purported, but ineffectual self-regulation advocated in recent decades. All this has resulted in inadequate and often inappropriate regulation.

Why is it so difficult to achieve meaningful coordination while everybody agrees that it is desirable? The 1950s and 1960s have been referred to as the Golden Age, a period of rapid reconstruction, growth and employment expansion after the destruction of the Second World War. It was also a period of beginning development and structural transformation in many post-colonial developing countries, albeit with mistakes and flaws, with the benefit of hindsight. This came to an end when deliberate multilateral coordination collapsed following President Nixon's decision to renege on its 1944 commitments as the basis for the post-war international monetary system. The end of the Bretton Woods system in 1971 contributed to poorer growth, greater volatility, more instability, slower progress in raising economic welfare and so on.

\section{Financial Crises}

International financial crises have had particularly devastating impacts on developing countries, including so-called 'emerging markets'. For example, despite non-involvement in the US subprime debacle, emerging stock markets collapsed much more than other stock markets, resulting in a reversal of capital inflows, which also adversely affected inflows of foreign direct investment. The crisis spread well beyond the developed economies, wreaking havoc among 'innocent bystanders' and resulting, inter alia, in much higher borrowing costs for legitimate borrowers in socalled emerging markets.

But in 2008 and 2009, the financial positions of many of these economies, especially in East Asia, were much stronger because of their earlier experiences. They had accumulated more foreign reserves and their fiscal balances were stronger. But many of these reserves evaporated rather quickly with the collapse of export prices following 2008, and especially from 2014. Needless to say, fiscal space for most of these economies also contracted very significantly.

Unfortunately, developing countries have generally been in very vulnerable positions, making it especially difficult to respond to such crises. Unlike for the US and the Eurozone, monetary policy instruments have been less effective for most such economies. Their situations are often worse when they have accepted more independent central banks with different imperatives and priorities.

Generally speaking, the fiscal requirements in order to pursue counter-cyclical fiscal policies have been much 
more stringent, and this has become even worse when fiscal authorities too have become more independent, as advocated by officials of the Washington-based international financial institutions. Policies, especially fiscal policies have been constrained by the orthodoxy of recent decades as these economies have had to deal with much more systemic and institutional procyclicality. Furthermore, productive capacities lost due to earlier liberalization and globalization have reduced the capacities and capabilities of many of these economies.

\section{Underlying Causes of Crises}

There are at least three underlying causes of the global financial and economic crises in recent decades. Since the collapse of the Bretton Woods system in 1971, a small handful of currencies, especially the US dollar, have basically served as reserve currencies for the world. This has allowed the issuers of these currencies to run massive trade deficits, contributing to ultimately unsustainable global imbalances in savings and consumption.

A second underlying cause has been growing financial fragility arising from the global financial 'non-system' in place since the collapse of the Bretton Woods system as well as macro-financial dynamics. The lack of coherence and coordination in the system has been exacerbated by the strong trend towards financial deregulation, liberalization and globalization over the past three and a half decades. Referring to this 'non-system' as an international financial 'architecture' is truly insulting to architects.

The third underlying cause of the global financial and economic crisis has been the ascendance, transformation and hegemony of the financial sector-often termed 'financialization'-over the past three to four decades. Finance is indeed a very important, if not essential handmaiden for the functioning of the real economy, but the term refers to the ascendance of the financial sector over the financing needs of the real economy. Partly as a consequence of financialization, decision-makers are now often more concerned with short-term financial indicators than with other basic economic indicators, usually presuming the former reflect the latter. This subordination of the real economy to finance is a fundamental part of the problem.

So, to address the root causes of crises, what is needed is much better, especially more appropriate regulation of the financial system, ensuring consistently counter-cyclical macro-financial institutions, instruments and policies, and subordinating the financial sector to the real economy. There is no simple prescription of how this is to be achieved, as circumstances vary considerably, both over time, with popular practices and trends, and also depending on extant frameworks.
The crises have catalysed many debates on these issues, some old, some new, for instance between Keynesian/ Minskyian economists and their opponents, between the supposedly Anglo-American and continental European worldviews, and between North and South. Any sustainable solution will clearly require extensive international cooperation and co-ordination.

\section{Global Financial Crisis}

Although recent and current international macro-financial coordination leaves a lot to be desired, there have been some efforts to improve the situation. For instance, in October 2008, at the time of the annual IMF-World Bank meetings, there were some efforts to improve coordination by the G-7 as well as in Europe soon afterwards. Unfortunately, these efforts did not achieve much.

Meanwhile, then President Sarkozy of France saw the problem and discussed holding a summit at the UN with the UN Secretary-General. He subsequently consulted US President Bush who insisted on hosting the first ever G20 summit in mid-November 2008 in Washington DC, though it must be noted that the G-20 Finance Ministers had been meeting for a decade after it was created by US Treasury Secretary Larry Summers and then Canadian Finance Minister Paul Martin after the 1997-1998 Asian crisis. In the following month, the G-20 group of finance ministers met in the White House at the level of heads of governments/states for the very first time, and has continued to meet annually since 2011. While the G-20 made some progress in its early years, its modest record has also been chequered.

When the financial crisis preceding the Great Recession broke out in late 2008, the credibility of the UN Secretariat's analytical work was greatly enhanced. This happened as the UN and the Bank of International Settlements (BIS) had been alone in warning, for some years, of the dangers posed by unregulated financial sector deregulation, including some related to the growing imbalances in the global economy. In contrast, most other international organizations-the IMF, World Bank and OECD-which monitor developments in the world economy had failed to see the crisis coming. Until the third quarter of 2008, all three of them were still predicting continued robust growth of the world economy, and at worst, 'soft landings' in the event of financial turmoil, including in the US.

A strong case for better international macro-financial coordination has been consistently made in the World Economic Situation and Prospects published by the UN Secretariat and prepared by its Department of Economic and Social Affairs (DESA) together with the United Nations Conference for Trade and Development (UNCTAD). For example, the 2009 Mid-year Update showed how better 
coordinated and more equitable fiscal stimuli would have benefited all parties-developed countries, developing countries, transition economies and, most of all, the least developed countries.

Thus, the UN system was in an enhanced position to lead the global response to the crisis. However, although there was agreement to develop and offer 'second opinions' to Member States on request, in practice, it was business as usual as each UN entity carried on with their own work programs with occasional mention of the crisis and its impacts. There was no coherent response and little sustained attempt to seriously address fundamental issues.

Meanwhile, although there have been some sporadic signs of recovery, economic stagnation in most developed economies seems likely to continue, with joblessness and underemployment continuing to rise. There is a consensus now that what is politely termed recovery is both uneven and easily reversible. Early withdrawal of stimulus measures in 2009 pushed the global economy into stagnation, especially as private consumption and investment spending remained weak.

Most developing countries still remain vulnerable, often with little fiscal space to be able to respond to shocks. Their policy space remains restricted, especially following the collapse of mineral and other primary commodity prices since 2014, and continued denial of the need for countercyclical macroeconomic policies by most influential policymakers. The poorest countries also faced the prospect of renewed hunger, as food price spikes and volatility continued after 2007-2008. Despite the moderation of these problems in later years, the push to cut food price subsidies threatens to eliminate the main cushion between international producer prices and consumer food prices.

Meanwhile, efforts to strengthen prudential regulations in developed countries have been indefinitely postponed since 2009 following growing opposition from the financial sector, once it had been rescued. Since then, there has been little serious discussion of reforms in the international financial system.

\section{New Deal}

In 2009, the UN Secretary-General called for a Global Green New Deal, seeking internationally coordinated fiscal stimuli, centred on major investments in renewable energy and other long-neglected global public goods. At its April meeting, the G20 successfully mobilized over a trillion dollars, mainly to enhance IMF resources. The UN emphasized promoting sustainable energy to address the looming climate challenge. In the face of limited private investments, it argued that public investments have to take the lead, to help quickly bring down the unit costs of renewable sources. The proposal was rejected as inappropriate owing to the much higher costs of renewable energy then. In fact, subsequent developments have shown that the UN was too cautious as the costs of renewable energy have fallen much faster than it anticipated, although the oil price collapse since 2014 has limited the competitiveness of renewable energy.

Another effort in the proposed New Deal involved strengthening world food security. This would involve encouraging investment in food agriculture, again with public investment leading, supplemented by aid. In addition, there was recognition of the inability to completely eradicate poverty and hunger without extraordinary measures involving 'social protection'. In so far as such measures would also enable beneficiaries to enhance their productive assets and capacities, they would ensure higher incomes and more investments, thus contributing to economic recovery, greater resilience and self-reliance in the medium term.

Recognizing the critical role of the 1944 Bretton Woods conference and the institutions it created for post-war recovery and post-colonial development, the UN also called for reforming the international financial system to better address new circumstances and challenges. The late 2008 second Financing for Development (FfD) conference in Doha also reiterated the Monterrey Conference's call to mobilize the international community for accelerated debt relief, improved tax co-operation, better developing country access to developed country markets, and enhanced developing country access to technology, especially for life-saving drugs and renewable energy.

If UN initiatives had not been blocked by some OECD countries, it is likely that the world would have developed a debt management framework to address the Icelandic and Greek debt crises as well as greater international tax cooperation to better address tax evasion and avoidance and tackle the fiscal constraints faced by so many governments today.

The June 2009 High Level Conference on the Global Financial and Economic Crisis made specific proposals for urgent actions, many of which were later elaborated by the Stiglitz Commission Report's recommendations. In early 2009, the UN system committed to support Member States to re-orient their macroeconomic and financial policy framework to include full employment as an explicit target for both developed and developing countries. But without credit facilities to support its policy advice, few countries have sought UN assistance on macro-financial management since 2008.

\section{Reforming the International Financial System?}

The growth in global interdependence poses greater challenges to policy makers on a wide range of issues and for countries at all levels of development. Yet, the mechanisms 
and arrangements put in place over the past three decades have not been adequate to the challenges of lack of coherence and coordination of global economic policymaking.

The 2008 financial crises have exposed some such gaps and weaknesses. Reforming the international economic governance architecture through the UN should address these problems. Although sometimes seemingly slow, the UN has a clear advantage in driving the discussion on reform because of its more inclusive and open governance. Lop-sided influence in the current international financial system is a principal reason why so many countries lack confidence in existing arrangements. Rebuilding confidence in such arrangements will enable all parties to feel they have a stake in the reform agenda.

But the UN is also suited to drive the discussion because of its long tradition of reliable work on international economic issues, including those related to finance. The UN Secretariat has developed and maintained an integrated approach to trade, finance and sustainable development, with due attention to equity and social justice issues. The ongoing 'secular stagnation' has again highlighted the interdependence of global economic relations, exposing a series of myths and half-truths about the global economy, the role of finance and the benign consequences of globalization.

These include the idea that the developing world has become 'decoupled' from the developed world; that unregulated financial markets and new financial instruments have ushered in a new era of 'great moderation' and 'stability'; and that macroeconomic imbalances, due to decisions in private household, corporate and financial sectors, are less dangerous than those involving the public sector. The UN Secretariat has consistently doubted such arguments, and warned that any unravelling of global macroeconomic imbalances would be unruly. Also, persistent asymmetries and biases in global economic relations would particularly hit developing countries, both emerging and least developed.

Not surprisingly, the UN Secretariat has also drawn attention to the close links between the financial crisis and the food and energy crises. A more integrated approach to handling these threats is needed, particularly to alleviate the downside risks for the poorest and most vulnerable communities. The UN Secretariat has a strong track record of identifying systemic threats from unregulated finance, warning against misplaced faith in self-regulating markets and offering viable solutions to gaps and weaknesses in the international financial system.

Special Drawing Rights (SDRs), the 0.7 percent aid target and debt relief, for example, were all conceived within the UN system during the 1960s and 1970s. From the 1980s, UN agencies have consistently warned against the excessive conditionalities attached to multilateral lending, promoted the idea of rules for sovereign debt restructuring, and expressed concern that international financial institutions were moving away from their traditional mandates of guaranteeing financial stability and providing long-term development finance.

During the 1990s, the UN warned against threats of economic instability, particularly in developing countries, from volatile private capital flows and the speculative behaviour associated with unregulated financial markets. The UN was among the very few warning Mexico in 1994 and the East Asian countries in 1997 that excessive liberalization could lead to crisis. The UN system was also almost alone among international institutions, to identify growing inequality as a threat to economic, political and social stability, and insisted early on measures for a fairer globalization.

More recently, the UN has insisted on the importance of policy space for effective development strategies, and particularly on the need for macroeconomic policies to support long-term growth, technological upgrading and diversification. Some OECD countries have sometimes opposed such work by the UN Secretariat, preferring a duopoly by the Bretton Woods institutions (BWIs) and the OECD. However, the combination of a strong track record and a core staff steeped in a tradition of an integrated approach places the UN Secretariat in an excellent position to host and guide needed discussions for reforming the international financial architecture.

\section{Inadequacy of Reforms and Possible Ways Forward}

International financial reforms remain unfinished and grossly inadequate. The view that has dominated thinking in the West since 2008 is that international macroeconomic policies need to focus on fiscal consolidation and austerity. There has also been a great deal of emphasis on reducing global trade imbalances which has resulted in growing protectionism and the decline of international trade growth. Furthermore, there has been a particular interest in strengthening exchange rates in the hope that this would reflect stronger economies and sound macroeconomic policy.

It is important to try to strengthen and improve international financial regulation so that it becomes much more coherent as well as effective. The unfortunate consequence of raising Basel III capital requirements has been to increase borrowing costs. Meanwhile, the Financial Stability Board, under the leadership of the Canadian Governor of the Bank of England, has made some progress, but has not adequately addressed the fundamental problem of what is termed 'shadow banking'. 
Much of the policy and reform discussion focuses on matters such as limiting executive remuneration. In a recent episode involving Credit Suisse, executives were expecting bonuses despite the company making huge losses. As a compromise, the management proposed reducing the bonuses by $60 \%$, but the fact remains that they still expect bonuses as virtual entitlements despite the company losing money.

Finally, it is important to emphasize that capital account or capital flows management or capital controls are very much needed. This is allowed by the IMF's Article 6, but has arguably been undermined by the General Agreement on Trade in Services, particularly the Financial Services Agreement of the World Trade Organization (WTO).

To sum up, it is important to develop a clear and shared understanding of priorities for international financial reform. It is crucial to allow, if not encourage governments, especially in developing countries, to retain the right to prudential risk management, which will include what are often referred to as capital controls. Second, it is important to ensure that monetary and financial policy is essentially counter-cyclical, rather than procyclical, because of the inherent tendency of the system to be procyclical. Third, it is important that the financial system better finances growth, not only output, but also employment growth. Fourth, and especially important for developing countries, instruments of development finance are especially crucial to support industrial policy or appropriate combinations of investment as well as technology development policies. Finally, there is far greater appreciation in recent years of the importance of ensuring that the financial system is supportive of initiatives to advance financial inclusion.

\section{Democratic Governance}

Meanwhile, the relationship between the Bretton Woods institutions (the World Bank and the IMF) and the rest of the UN system has changed over time. The BWIs were initially conceived as part of the post-war system of multilateral governance to ensure the conditions for peace, growth, development, employment and prosperity. Today, however, the BWIs' governance arrangements remain very different from the rest of the UN system, with all its variety. This is part of the problem. To put it crudely, the Bretton Woods or Washington institutions are governed by a principle of 'one dollar, one vote', whereas in New York, the UN is governed by 'one country, one vote', at least with respect to the General Assembly.

Europe is over-weighted in the BWIs while developing countries are generally under-weighted, even in terms of economic output. These governance arrangements in the BWIs have created a sense of exclusion; developing countries feel they are not fairly represented, especially with the dilution of the weight of the basic vote over the decades. For example, in the mid-1940s, there were 44 members of the BWIs, with the weight of the basic vote for the 44 totalling 11.4 percent. Today, there are 189 members. So, if the weight of the basic vote remained the same, the total weight of the members would be just under half $(189 / 44 \times 11.4$ percent $)$. A decade ago, just before a modest reform, it was only 2.2 percent, or $<5$ percent of what it should have been! Such governance issues inevitably undermine legitimacy, and thus constrain more effective global coordination. But of course, there are other problems as well.

For many years now, there have been some important differences across the Atlantic, arguably since the 1960s. During the recent crisis, the European approach relied initially on its long-standing automatic stabilizers, arguing that Europe did not need the big fiscal stimulus which the US and the UK-unusually-advocated in 2009. Later, the European Central Bank warned incessantly of the threat of inflation, while the IMF seemed to take the view, like the rest of the UN system, that the bigger threat was that of protracted deflation, recession and stagnation.

Under the leadership of then UK Prime Minister Gordon Brown, the G-20 committed to a huge capital infusion for the IMF in April 2009. It would have been better if the G-20 had provided this capital boost on condition that the IMF reform itself to better serve the developing countries, especially those most marginalized by existing governance arrangements. Without reforming itself sufficiently, the IMF has continued to suffer from legitimacy and credibility problems, undermining its ability to provide more effective leadership.

While the IMF is undoubtedly very important, there is no World Finance Organization or Authority, unlike with trade, where there is the WTO. Through its General Agreement on Trade in Services (GATS), it has been the WTO which has been legislating on financial services liberalization. Besides the WTO, the Bank of International Settlements, the Basel Committee on Banking Supervision, the Financial Stability Board and other international organizations where developed economies have effective control, have jurisdiction in cross-border financial matters. Meanwhile, important UN initiatives, e.g. the 2002 Monterrey Financing for Development (FfD) Conference, have been largely ignored in various discussions on international financial reform.

Almost a decade after the 2008 financial crisis erupted, it remains doubtful whether there is enough shared political commitment to see through needed global financial reforms. It took fifteen years, a world war and Roosevelt's extraordinary leadership before the world was able to reform the international financial system in 1944. Have we learned from history? 